\title{
Arendt and the Modern State: Variations On Hegel in The Origins of Totalitarianism
}

\author{
Roy T. Tsao
}

\begin{abstract}
Hannah Arendt's The Origins of Totalitarianism (1951), unlike her later books, is centrally concerned with the nature and fate of the modern state. The book presents a series of political pathologies - antisemitism, imperialism, tribalism, and totalitarianism - that Arendt regards as the result of failures in the state's dual mission to integrate diverse social groups into a single body politic, and to uphold the uniform rule of law for all. Her underlying conception of the state bears a striking, though unacknowledged affinity to that of Hegel. Like Hegel, moreover, she argues that citizens' mutual recognition of one another's human rights, as mediated through state institutions, is an indispensable condition for full human self-consciousness and agency. Her version of this argument is developed first through an excursus on the origins and effects of racism among Europeans living in Africa, and then through an analysis of the unique plight of stateless refugees.
\end{abstract}

The book that established Hannah Arendt's reputation as a political thinker was The Origins of Totalitarianism (1951). ${ }^{1}$ Its account of totalitarianism was highly influential in its time, and the book is still widely read today. And yet the full measure of Arendt's ambitious project in political theory in this first major book of hers has rarely been taken. One reason for this is simply that the book encompasses so much disparate historical materialranging from the role of Jewish bankers in seventeenth-century state finances, to European imperialism in Africa, to the police methods of Stalin - that its larger philosophical claims about the nature and function of political institutions tend to get lost amid its episodic narratives. Many of the most important of those theoretical claims are fairly tangential to what Arendt has to say about totalitarianism and its historical origins; the book's rather misleading title (which Arendt herself came to regret) lulls the

I would like to thank Peg Birmingham, Margaret Canovan, George Kateb, Jerome Kohn, Patchen Markell, Larry May, Gaelen Murphy, and Walter Nicgorski, along with this journal's manuscript reviewers, for many helpful comments on earlier versions of this essay.

1. Hannah Arendt, The Origins of Totalitarianism [1951], rev. and expanded edition (New York: Harcourt, 1973). Henceforth abbreviated OT. All parenthetical page references in the body of this essay refer to this text; all of the passages cited also appear in the differently paginated first edition. 
reader into discounting the significance of such claims, and thus missing the full scope of her theoretical project. ${ }^{2}$ Moreover, students of Arendt's thought have generally approached the book from the retrospective vantage of her later works like The Human Condition (1958) and On Revolution (1963). ${ }^{3}$ In fact, however, Arendt's theoretical priorities underwent a substantial shift between the time she wrote The Origins of Totalitarianism and those later books. ${ }^{4}$ As a result of this shift, The Human Condition and Arendt's other later writings are an inadequate guide to the concerns of the prior book. ${ }^{5}$ The central arguments of that earlier theory deal with a matter to which she devotes virtually no attention in her later writings: the modern constitutional state. In The Human Condition, Arendt mentions the modern state only to dismiss its significance to her theoretical concerns. ${ }^{6}$ While she shows greater interest in modern constitutionalism in $O n$ Revolution, she devotes far more attention to problems associated with the founding of states and the framing of their constitutions than with their regular functions.

In The Origins of Totalitarianism, by contrast, she attaches paramount importance to the modern state's dual function of integrating its diverse populations into a single body politic and upholding the rule of law for all. To be sure, Arendt never sets out a detailed

2. Arendt expressed her regret over the misleading nature of the title of The Origins of Totalitarianism in her published reply to a Eric Voegelin's review of the book for The Review of Politics. Arendt, "A Reply," Review of Politics 15/1 (1953): 7684, reprinted in Arendt, Essays in Understanding: 1930-1954, ed. J. Kohn (New York: Harcourt, 1994), pp. 401-408. Unfortunately, Arendt's remarks there about the book's intended structure were in some respects no less misleading; on this matter, see Roy T. Tsao, "The Three Phases of Arendt's Theory of Totalitarianism" Social Research 69, no. 2 (2002): 589-90.

3. Arendt, The Human Condition (Chicago: University of Chicago Press, 1958); Arendt, On Revolution [1963] rev. ed (New York: Viking, 1965).

4. The magnitude of that shift is partially masked by the fact that all editions of the book since 1955 have included a new concluding chapter ("Ideology and Terror") that more closely reflects Arendt's theoretical concerns in The Human Condition. On the evolution of the text, see Ursula Ludz, "Hannah Arendt und ihr Totalitarismusbuch: Ein kurzer Bericht über eine schwierige Autor-WerkGeschichte," Hannah Arendt-Studien 1: Totalitäre Herrschaft und republikanische Demokratie, ed. Antonia Grunenberg (Frankfurt: 2003), pp. 81-92.

5. That is not, however, to deny that some (though not all) of the underlying concerns of The Origins of Totalitarianism would remain important to Arendt in her later writings as well. For these continuities, see Margaret Canovan, Hannah Arendt: A Reinterpretation of Her Political Thought (New York: Cambridge University Press, 1992), p. 7 and passim.

6. See Arendt, The Human Condition, p. 43. 
normative model of a successful state along those lines. Instead, she addresses the matter obliquely, by focusing on the disastrous effects that she traces to the historical failure of the states of continental Europe to carry out those two functions. Much of her argument in the book takes the form of a narrative about the inherent weaknesses of the continental European state from its emergence in the seventeenth and eighteenth centuries to its near-universal demise in the middle of the twentieth at the hands of Hitler, Stalin, and their various minions. (For Arendt, a totalitarian regime is not the aggrandizement of the modern state, but its ultimate antithesis.) Her long detours from that narrative supplement her argument by illustrating a set of "perversions of human self-consciousness" that she associates with the failure of law-governed political community.

Arendt's argument about the state, its essential functions, and its fatal vulnerabilities appears primarily in The Origins of Totalitarianism's first two parts, "Antisemitism" and "Imperialism." As it happens, she had written nearly all of those first two parts of the text before she even arrived at her views on totalitarianism; despite what the title may seem to suggest, her decision to add a third part on totalitarian movements and regimes was something of an afterthought. ${ }^{7}$ This essay will undertake an examination of that argument about the state as it appears in those first two parts of the book. ${ }^{8}$ (I will conclude with a brief look at the theory of totalitarianism in the third part.) By highlighting how particular sections of the sprawling text contribute toward that argument, I hope also to show how the seemingly disparate contents of the book fit within the frame of a comprehensive project in political theoryArendt's first.

To help bring out the structure of that project, I will be considering it in relation to the theory of the state of an earlier thinker who shares many of the same concerns: Hegel. The suggestion that Arendt's project in this work has important affinities with Hegel's political thought may sound rather unlikely. She nowhere acknowledges any intellectual debt to him (whether in this book or elsewhere), and her published

7. See Tsao, "The Three Phases of Arendt's Theory of Totalitarianism," 582-91; Canovan, Hannah Arendt: pp. 18-19.

8. Prior to their incorporation in The Origins of Totalitarianism, Arendt's treatment of several of the themes discussed in this essay made their first appearance in the pages of The Review of Politics. See Arendt, "Race-Thinking Before Racism," Review of Politics 6/1 (1944): 36-73; "Imperialism, Nationalism, Chauvinism" Review of Politics 7/4 (1945): 441-63; "The Nation," Review of Politics 8/1 (1946): 138-41. 
comments about his philosophy (occurring in her later works) are almost invariably negative. ${ }^{9}$ (Much the same, however, is true of what Arendt said in print about her former teacher Heidegger, whose impact on her thought can hardly be doubted. ${ }^{10}$ Not surprisingly, then, Hegel has almost never been counted among Arendt's influences. ${ }^{11}$ Yet the unacknowledged affinities between Arendt's project in The Origins of Totalitarianism and Hegel's political philosophy are striking nevertheless. Arendt's understanding of each of the two essential functions she attributes to the modern state in this book corresponds to a comparable tenet in Hegel's own theory of the state. Like Hegel, Arendt believes that the basic challenge confronted by the modern state in sustaining its people's allegiance to a single political community lies in the conflicting, particularistic interests that arise with the emergence of a market-oriented, "bourgeois" society. With more than a century's hindsight, Arendt takes a different, and darker, view of the forms those conflicting interests had taken. Even so, her account of the syndromes of political alienation that resulted

9. These unfavorable comments usually concern Hegel's philosophy of history, which she (erroneously) interpreted as a conception of history as a quasi-natural process. See Arendt, "The Concept of History: Ancient and Modern" [1958] in Between Past and Future (New York: Penguin, 1977), pp. 85-86; Arendt, On Revolution, pp. 51-54.

10. Curiously, Arendt's debt to Heidegger seems much less pronounced in The Origins of Totalitarianism (at least its first edition) than in her later works. (The book's only overtly Heideggerian motif, its account of what Arendt calls "loneliness" in mass society, occurs in "Ideology and Terror," a chapter added only in the book's later editions.) This may have something to do with the fact that Arendt had been personally estranged from Heidegger at the time she wrote the book; she renewed contact with him in 1950, after the manuscript was already completed.

11. There are some exceptions. The pertinence of Hegel to Arendt's later work, particularly The Human Condition, has been noted, in passing, in Judith Shklar, "Hannah Arendt as Pariah" [1983] in Political Thought and Political Thinkers (Chicago: University of Chicago Press, 1998), p. 370; J. M. Bernstein, "From Self-Consciousness to Community: Act and Recognition in the MasterSlave Relationship" in The State and Civil Society: Studies in Hegel's Political Philosophy, ed. Z. A. Pelczynski (New York: Cambridge University Press, 1984), p. 34; and George Kateb, Hannah Arendt: Politics, Conscience, Evil (Totowa, NJ: Rowman and Allanheld, 1984), p. 44n.2. This matter has been more recently explored by Allen Speight in "Arendt and Hegel on the Tragic Nature of Action," Philosophy \& Social Criticism 28/5 (2002): 523-36. Some commonalities and differences between Arendt's views on modern society and Hegel's (with brief remarks on The Origins of Totalitarianism) are discussed in Jean Cohen and Andrew Arato, Civil Society and Political Theory (Cambridge, MA: MIT Press, 1992), pp. 177-200. 
from the European state's historical failure to contain and surmount those conflicts may be regarded as an imaginative extension of the underlying concerns that had led Hegel to lay great stress on the socially integrative function of political institutions. The consonance between Arendt's arguments and Hegel's is no less striking with respect to her claims about the state's still more fundamental function of sustaining a rightsbased legal order. Like Hegel, Arendt holds that the reciprocal recognition of rights among the citizens of legally constituted political community is an indispensable condition for an individual's attainment of full human agency, so much so that a life spent outside such a community is in a sense not fully human. To be sure, Arendt's approach to these problems differs from Hegel's in a number of important ways. She has no use for the notoriously obscure "speculative logic" upon which his political philosophy is supposed to be based, nor for his vision of reason's fulfillment in history. For these reasons, and others, it would be difficult to label Arendt's overall project in The Origins of Totalitarianism as "Hegelian" in any conventional sense. Even so, attention to the recurring affinities between particular arguments of hers and the comparable ones in Hegel serves to illuminate that project's otherwise elusive structure. By the same token, attention to Arendt's divergences from Hegel's precedent helps to bring some of the more original aspects of that project into sharper focus.

There is no direct evidence that Arendt self-consciously took Hegel's theory of the state as a starting point for her project in this work. But then again very little is known about the sources of Arendt's political thought during this phase of her career. ${ }^{12}$ The story of her transformation from an apolitical student of Heidegger and Karl Jaspers to the author of a landmark work on totalitarianism has generally been told as the direct result of the shock of the political events that forced her to flee Germany in 1933. But another set of circumstances about her life in the 1930s may be pertinent as well. Prior to her emigration to the United States in 1941, Arendt spent most of her exile years in Paris, at the very moment that Hegel had become a dominant presence in French intellectual life. She herself

12. Arendt's recently published Denktagebuch, a collection of notebooks whose dated entries provide a detailed view to the sources and development of her later thought, begin only in 1950; the manuscript for The Origins of Totalitarianism was completed the previous year. See Arendt, Denktagebuch: 1950 bis 1973, ed. Ursula Ludz and Ingeborg Nordmann (Munich: Piper, 2002). 
personally knew many of the figures who were most directly responsible for Hegel's ascendance in France at that time. Two of them, Alexandre Koyré and Jean Wahl, became her good friends. A third, Eric Weil, was married to Anne Weil (née Mendelssohn), Arendt's lifelong best friend since their youth together in Königsberg. ${ }^{13}$ Arendt also knew Alexandre Kojève, and had apparently attended some of his famously influential seminars on Hegel's Phenomenology of Spirit. ${ }^{14}$ At a time when the English-speaking world was unreceptive to Hegel's philosophy-and especially its political side-these figures were rediscovering and exploring many of the very themes in Hegel's thought that seem to reverberate in Arendt's book. Wahl was responsible for introducing Hegel's ideas about alienation to French intellectual circles. ${ }^{15}$ Weil's studies of Hegel's theory of the state (published in book form only later) would help acquit Hegel's politics of its anachronistically presumed guilt by association with Bismark's (and Hitler's) expansionist German state. ${ }^{16}$ Kojève's imaginative (if notoriously one-sided) reading of the Phenomenology of Spirit's dialectical encounter between master and slave provided the most famous exposition of Hegel's conception of mutual recognition as a condition for human self-consciousness and freedom. ${ }^{17}$ Arendt's contacts with these figures during her Paris years may well have been among the formative influences on her efforts to arrive at a political theory of her own in the next decade. At very least, it

13. For Arendt's friendships with Alexandre Koyré and Jean Wahl, see Elisabeth Young-Bruehl, Hannah Arendt: For Love of the World (New Haven: Yale University Press, 1982), pp. 117, 245, 251. Anne Weil, the wife of Eric Weil, is mentioned throughout Young-Bruehl's biography of Arendt and was apparently a major source for it. For the influence in France of Koyré, Wahl, and Eric Weil as interpreters of Hegel, see Michael S. Roth, Knowing and History: Appropriations of Hegel in Twentieth-Century France (Ithaca, NY: Cornell University Press, 1988).

14. Young-Bruehl, Hannah Arendt, pp. 116-17. According to Young-Bruehl, both Arendt and her first husband Günther Stern attended some of Kojève's Hegel seminars at the École Pratique des Hautes Études, which ran from 1933 to 1939; Young-Bruehl mentions no specific dates. The partial list of participants in those seminars that Michael Roth has compiled from incomplete official records includes one "Stern" for the 1935-36 year. See Roth, Knowing and History, p. 226.

15. Jean Wahl, Le Malheur de la conscience dans la philosophie de Hegel (Paris: Rieder, 1929).

16. Eric Weil, Hegel et l'état (Paris: Vrin, 1950).

17. The notes Kojève prepared for these seminars were later assembled for publication by Raymond Queneau. See Alexandre Kojève, Introduction to the Reading of Hegel, ed. Allan Bloom (New York: Basic Books, 1969). 
is plausible to suppose that such ideas of Hegel's could well have been somewhere in the back of her mind when she came to write The Origins of Totalitarianism, given the evident affinities of her arguments with some of his own.

\section{State, Society, and Antisemitism}

Writing in the early nineteenth century, Hegel had been the first major political thinker to see that the emerging market economy had created separate sphere of "civil" (or "bourgeois") society (bürgerliche Gesellschaft), standing between that of the private household and that of the state. Unlike in the ancient world, for which he had posited a sharp divide (or tragic conflict) between the enclosed, particularistic perspective of the family and the collective perspective of the community, this modern sphere of society allowed individuals to satisfy their particular interests while transacting business with a wider public. ${ }^{18}$ Hegel sees this as a salutary development; in seeking the satisfaction of his own needs, each participant in the market economy must suit his productive activity to the needs of others, and develop his abilities accordingly. ${ }^{19}$ Yet Hegel rails against the classical liberal notion that the body politic (the "state") may be conceived as no more than a contractual arrangement among the members of such a society. ${ }^{20}$ In his view, the state requires a more substantial basis of allegiance from its citizens than such an arrangement could generate. For this reason, he sees a need for a set of intermediate institutions that serve to anchor the state in society and orient the individual toward the larger political community. These institutions include professional and trade organizations, which are meant to temper the venal propensities of commercial life. ${ }^{21}$ They also include representative bodies that give people a voice in government, on the basis of their membership in such civil associations. In Hegel's view, the measure of the success for such mediating institutions is their capacity to prevent the members of society from confronting the state "ei-

18. Hegel, Philosophy of Right [1821] ed. A. Wood (New York: Cambridge University Press, 1991) [hereafter abbreviated $P R], \S \S 182-83$.

19. $P R \S 187$.

20. $P R \S 258$.

21. $P R \S 253$. 
ther as a simple undifferentiated mass or as a crowd split up into atomic units." 22

This kind of organic integration of state and society is precisely what Arendt believes the modern states of continental Europe failed to achieve. Much of The Origins of Totalitarianism's first two parts is concerned with various aspects of the resultant conflict between the state and particularistic interests in society. As Arendt tells it, the conflict dates back to the first emergence of the modern state in the era of royal absolutism, and it remained unresolved throughout the later period of the constitutional nation-state's consolidation and evolution. The modern state's claim to legitimacy rested on the promise of a uniform, impersonal legal order, abolishing the traditionally sanctioned, pervasively hierarchical structures of feudalism (p. 11). Its "supreme task" was "to protect and guarantee man's rights as man" (p. 230). But the separate sphere of "society" that emerged at the same time as the state's uniform political and juridical order lacked the same homogeneity. Where Hegel had seen (or looked forward to) a harmonious division of society into functional sectors (agriculture, commerce, and the like), Arendt looks back on a discordant division among social classes with conflicting economic interests. Individuals' actual interests were dictated not by their equal citizenship in the body politic, but by their membership in a particular social class (landowner or peasant, employer or worker) and the relations between those classes (pp. 12-13, 314). It was only the concomitant rise of the modern Western notion of the "nation"-which posited the existence of a community based on shared historical or linguistic heritage, irrespective of class membership - that made it possible to sustain any broad-based allegiance to the body politic as a whole. Arendt notes that this development had the pernicious effect of partly transforming the state "from an instrument of law to an instrument of the nation," thereby obscuring its fundamental mission as the guarantor of rights for all (p. 230). And yet, she argues, not even this troublesome fusion of state and nation could suffice to heal the breach between state and society. Except in rare moments of "national" crisis, the nation-state's citizens dealt with the state only insofar as it advanced or hindered their particular class interests. Parliamentary politics was thus the business of class-based parties that promoted and brokered such interests but that (unlike in the two-party systems of Britain or the United 
States) assumed little pretense of responsibility for the body politic as a whole (pp. 251-52). In Arendt's view, the ultimate consequence of those class-based politics was to discredit the authority of the state and the legal order it was supposed to represent. And the situation became only worse when the class system itself finally broke down, amid successive economic shocks following the First World War. The result was the rise of dangerously alienated "masses"-agglomerations of socially and politically "atomized" individuals who shared only an embittered, cynical anger toward the state's discredited institutions (pp. 314-15).

Arendt's understanding of the clash between state and society is set forth most fully in The Origins of Totalitarianism's first part, "Antisemitism." On the usual view that modern antisemitism has its roots in a long history of religious intolerance, that would seem an incongruous place for it. But Arendt's concern in this part of the book is actually not the history of anti-Jewish animus as such, but rather the relatively recent rise of secular antisemitism as the basis for efficacious political agitation of various kinds. ${ }^{23}$ In particular, what she seeks to explain is how, at various times and in various places since the late eighteenth century, such secular antisemitism could be used so effectively by disparate social groups to rally support for seemingly unrelated grievances against the institutions of the modern state (pp. 9-10). How is it, she asks, that the fate of one tiny, powerless minority could become such an incendiary political issue in countries all across the continent, not just in Germany but all over Europe? Her answer to that puzzle lies in the anomalous historical position of the Jews in relation to the long-simmering conflict between state and society. Although excluded from the class structure of society, a small number of prominent, politically privileged Jewish families had for generations served as the bankers to both royal and republican governments, over a period when the leading social classeswhether the waning nobility or the rising bourgeoisie-were for their part loathe to contribute to the state's expansion (p. 98). As

23. This more limited focus accounts for the otherwise inexplicable way in which Arendt can refer in passing to a "religiously determined, mutually hostile past" between Christians and Jew reaching back to the recesses of European history, or to the "ubiquitous hatred of Jews" in the "backward countries" of Eastern Europe, while dismissing the significance of such factors to her argument (OT, pp. xii, 29). 
a result, Arendt argues, the Jews in general became closely identified with the affairs of the state, and kept that reputation long after its factual basis had declined. This reputation as a shadowy presence behind the state made the Jews a convenient proxy target for particular classes' hostility toward the state, first among the declining nobility in the late eighteenth century and then again among the ruined "petite bourgeoisie" of tradesmen and shopkeepers in the last third of the nineteenth (pp. 31, 37). For Arendt, what is most revealing about these groups' antisemitic agitation is not simply the vulnerability of the Jews to their attacks, but that of the state itself.

Arendt's analysis of antisemitism culminates with a chapter on the Dreyfus affair in France at the turn of the last century. That famous "affair" had begun in 1894, when a military tribunal wrongly convicted a Jewish army colonel, Alfred Dreyfus, for treason; it eventually ended, after a string of revelations about falsified evidence, with Dreyfus's ambiguous acquittal on appeal a dozen years later. For much of the time in between, controversy over every aspect of the case had rendered the French nation into two profoundly hostile camps, the long-beleaguered Dreyfusards and their intransigent opponents. What gives the episode its paradigmatic significance for Arendt is chiefly the anti-Dreyfusards' nearly successful use of antisemitism as a tactical device to undermine the very foundations of France's Third Republic. She accordingly notes that the two groups that did the most to make the alleged case against Dreyfus a matter of avowedly antisemitic principle-on the premise that a Jewish colonel must be a traitor, whatever the evidence, and that the officers who framed him must somehow be the true victims-were precisely those whose loyalties to the republic were weakest: the French Army's officer corps, still an enclave of aristocratic caste privilege, and its members' Jesuit confessors, whose order was then a bastion of opposition to the secular state (pp. 101-102). ${ }^{24}$

The hero of Arendt's version of this drama is Georges Clemenceau, whose tireless championing of Dreyfus' cause

24. In discussing the Jesuits' role in fomenting antisemitism in the Dreyfus affair, Arendt does not attribute their motives to their religious beliefs as such, but rather to their frankly antirepublican ambition to recapture "a political share in the management of the state" (OT, p. 104). In this regard, it is worth noting that she makes a point of praising the later courage of Catholic bishops and parish clergy in standing up for French Jews against the German occupiers and the Vichy authorities (OT, p. 93). 
eventually rallied the better part of the French public to the Dreyfusard side. What distinguished Clemenceau among Dreyfus's defenders, in her view, is that he alone recognized that the fragile French Republic itself was at stake and that the abstract principles of justice and equality upon which it rested were worth standing up for (p. 113). That is not to say, however, that Arendt believes that the abstract, "republican" tradition that she takes Clemenceau to represent holds the answers to the modern state's failure. On the contrary, she portrays Clemenceau as a tragic, isolated figure, who in later years grew ever more aloof from "the true people of France" he spoke for. That, she suggests, is because his true following was composed of individuals with nothing but their decency in common, and who parted ways as soon as the crisis had passed (p. 114). For this reason, she says, Clemenceau himself could not clearly tell them apart from the "mob" that his opponents had incited, some of which eventually swung over to the Dreyfusard side (pp. 112, 115). Arendt's mixed judgment on Clemenceau's success and tragedy indicates both her proximity to and distance from Hegel on the question of political integration. Her admiration for Clemenceau's republican principles sets her apart from Hegel's endorsement of (constitutional) monarchy. And yet she shares in Hegel's belief that citizenship is meaningful only through the channels of intermediate associations and institutions that provide a lasting link between the individual and the state. As she puts it, much later on in the book, "Democratic freedoms may be based on the equality of all citizens before the law, yet they acquire their meaning and function organically only where the citizens belong to and are represented by groups or form a social and political hierarchy" (p. 312).

\section{Imperialism, the Bourgeoisie, and the Mob}

The Origins of Totalitarianism's second part, "Imperialism," concerns still more radical threats to the institutions of the constitutional state and the integrity of the body politic. Starting in this second part of the book, moreover, Arendt considers not only these threats' outward expression, but also the "dangerous perversions of human self-consciousness" that she says bring them about. The first of these threats is modern imperi- 
alism. Arendt dates the start of imperialist expansion to the "scramble for Africa" that followed the discovery of diamonds and gold in South Africa in the 1870s and eighties. Within a few decades, the European powers had not only partitioned the entire African interior among themselves, but had also ensnared all of Asia in their competing spheres of influence. Arendt emphasizes the fact that unlike all previous ventures of European empire-building, this wave of expansion was unaccompanied by any real attempt to incorporate the seized territories into an enlarged body politic. For the first time, the sheer expansion of power, in the form of monopoly access to natural resources and the ability to levy colonial troops, became the major European countries' permanent political aim (pp. 126-27). This made for a dangerously volatile competition among the major powers, finally sparking the First World War. It also tended to corrode state institutions at home, as representative government was increasingly supplanted by administrative rule in the service of global power politics. According to Arendt, this new form of power politics arose through the introduction of standards that were not political in origin at all, but derived from the realm of commercial market competition. She attributes that sinister innovation to a new phenomenon that she calls "the political emancipation of the bourgeoisie" (p. 123). By this Arendt means not the bourgeoisie's political enfranchisement (which had occurred long before), but rather the (self-) "emancipation" of the bourgeoisie in the late nineteenth century from its own former, negative disposition toward politics. No longer content to accumulate capital in the commercial marketplace, and to expect nothing from the state but noninterference in its affairs, this newly assertive bourgeoisie seized the reins of state power to advance its own pursuits.

Arendt argues that the immediate impetus for imperialist adventures came from the need to find lucrative overseas outlets for the accumulated "superfluous wealth" of the bourgeoisie, who then agitated for the state to protect their investments abroad through military intervention. ${ }^{25}$ The role she ascribes to the bourgeoisie gives her account a passing resemblance to the theories of Marxist writers like Rosa Luxemburg, Rudolf

25. $O T$, pp. 135, 148. Arendt's understanding of the economic dimension of imperialism is much indebted to J. H. Hobson's classic study of the subject. See Hobson, Imperialism [1902], $3^{\text {rd }}$ ed. (London: Allen and Unwin, 1938), pp. 78, 85, 361. 
Hilferding, and Lenin, all of whom she cites. ${ }^{26}$ Yet Arendt avoids attributing the drive for imperialism to any purely economic processes; she disparagingly remarks that socialists "were still probing the economic laws of imperialism when the imperialists themselves had long since stopped obeying them" (p. 152). Imperialism, she says, should not be considered "the last stage of capitalism" - as Lenin, for one, had claimed-but rather "the first stage in political rule of the bourgeoisie" (p. 138). ${ }^{27}$ Rather than treat imperialism as the natural outcome of bourgeois economic production, as those Marxist writers had done, she views it instead as the perverted application of certain "bourgeois" ambitions to a previously separate political sphere. She is less interested in the economic logic of capitalism than in what she takes to be the bourgeois mentality-and the conception of powerthrough-accumulation that flows from it. On her view, the bourgeois ethos was only superficially committed to capitalist free enterprise; its adherents' true ambition was always to corner all markets and swallow up any would-be competitors, and in that way to accumulate an extortionate monopoly on whatever forms of power were within reach.

For a view to the bourgeoisie's "hidden desires and secret convictions," Arendt turns to the thinker she calls "the only great philosopher to whom the bourgeoisie can rightly and exclusively lay claim, even if his principles were not recognized by the bourgeoisie for a long time"-Thomas Hobbes (p. 139). Arendt takes Hobbes's Leviathan as the prophetic summation of the bourgeois "philosophy of power" that would reshape the world two centuries after he wrote. She contends that Hobbes's account of human behavior-with his notorious postulation of "a perpetual and restless desire of power after power" on the part of all mankind $^{28}$ - is in fact no more than a clear-sighted insight into the

26. $O T$, pp. 148-49. Arendt credits Luxemburg in particular for her "brilliant insight" into the dependence of capitalism on noncapitalist economies. But even that laudatory reference is somewhat misleading: while Arendt represents that claim as a thesis concerning imperialist expansion in particular, it actually concerns what Luxemburg takes to be the conditions for the accumulation of capital as such. See Rosa Luxemburg, The Accumulation of Capital [1913] (New York: Monthly Review, 1968), pp. 452 and passim.

27. Arendt's implied rejoinder to Lenin in this statement is noted in Seyla Benhabib, The Reluctant Modernism of Hannah Arendt, $2^{\text {nd }}$ ed. (Lanham, MD: Rowman and Littlefield: 2003), p. 77.

28. Thomas Hobbes, Leviathan, ed. C. B. Macpherson (New York: Penguin, 1981), chap. 11, p. 161. 
conditions of the then newly emergent bourgeois society, in which each individual confronts all the rest as nothing but competitors for the market's fickle esteem. (The fact that Hobbes abstracts the individual's jostling for comparative advantage from any context of actual commercial relations makes his theory all the more suitable for Arendt's purposes, for she herself does much the same.) Arendt latches on to an implication of Hobbes's theory that his readers often overlook: that the actual power at the disposal of the supposedly omnipotent sovereign is-necessarily-conceived on the very same terms as that of the competitive individuals in this society, and is therefore prone to exactly the same kind of instability. The individuals in Hobbes's society need their "state" to protect themselves from one another's potential violence, but the power of that state itself amounts to no more than those members' accumulated potential for violence against any and all outsiders. The sovereign's power depends entirely on its ability to attract and marshal the strength of its adherents, yet its claim upon their loyalty lasts only so long as it succeeds in protecting them against the forces of any rivals it has thus far failed to subdue. ${ }^{29}$ Hobbes himself may have wished for peace; Arendt sees the inevitable outcome of his system to be a program of limitless expansion on the part of empires competing to master the Earth.

As before, Arendt's argument responds to a theoretical problematic that she shares with Hegel. To be sure, the rapacious, domineering bourgeoisie of "Imperialism" seems a far cry from the restrained, public-spirited burghers that Hegel had placed in the bosom of his well-ordered state. But that is exactly the point. For Hegel, the success of the modern state depends crucially on the capacity of its political and social institutions to give the business-minded members of commercial society a personal stake in matters of public concern, and a recognized place within their community. That is why he had so strongly opposed the notion that the state might be conceived on the model of a contract among private persons, as Hobbes had done. $\mathrm{He}$ had argued that without membership in such mediating institutions, the isolated, private individual would be driven to a dangerously insatiable chase after material success to the neglect of all else. ${ }^{30} \mathrm{He}$ thus had insisted-taking his terms from

29. See Leviathan, chap. 21, p. 272.

30. See especially $P R \S 253$. 
the French-that the members of the state must be able to regard themselves as both bourgeois and citoyens at once. ${ }^{31}$ Arendt, too, defines the issue with reference to the French duality of bourgeois and citoyen. Only for her the decisive fact is the failure of the two sides to fuse, leaving the bourgeois without any civic orientation (pp. 144, 255). She thus describes the bourgeois mentality as the product of a certain form of alienation from the body politic:

Deprived of political rights ... [and excluded] from the management of public affairs that involve all citizens, the individual loses his rightful place in society and his natural connection with his fellow-men. He can now judge his individual private life only by comparing it with that of others, and his relations with his fellow-men inside society take the form of competition (p. 141).

Note how Arendt suggests that the untrammeled competitiveness that pervades bourgeois society follows from the individual's political isolation (rather than the reverse). In her account, the lack of any true civic identity leaves the bourgeois individual with nothing but a private identity that can gain validation only through ceaseless competition with all the rest. The only political enterprise of which such men are capable is to pool their power so as to compete with other such bodies. Thus the seeming liberation of the bourgeois individual from traditional hierarchies results instead in his utter debasement before a collective leviathan, "which itself is constructed in such a way that it can devour the globe simply by following its own inherent law" (p. 146).

By the close of Arendt's account of this crypto-Hobbesian mentality, the bourgeoisie itself has all but ceded from view. In its place stands another social group, whose overt conduct corresponds more directly to that mentality's half-hidden dictates. It is a group she had already introduced in "Antisemitism": the "mob." Its ranks are drawn from among the déclassé vic-

31. The usual term in German for "citizen," "Bürger," like the French "bourgeois," referred originally to the privileged condition of medieval towndwellers; it lacks the political connotation of the French citoyen. See Hegel, Lectures on the History of Philosophy, trans. E. S. Haldane and F. Simson (Lincoln, NB: University of Nebraska Press, 1995), 2: 209; compare $P R$ \$261. See also Hegel, Jenaer Realphilosophie, ed. J. Hoffmeister (Hamburg: Meiner, 1967), p. 294 (cited in Shlomo Avineri, Hegel's Theory of the Modern State [New York: Cambridge University Press, 1972]). 
tims of market competition, left to get by in the more or less criminal rackets that thrived in the bowels of capitalism. This is one aspect of Arendt's account that Hegel had directly anticipated. Hegel was acutely aware that the market economy not only engenders poverty in the midst of its wealth, but in so doing also spawns a vicious "rabble" (Pöbel), whose members are resentful toward society and suspicious of the state. ${ }^{32}$ Arendt's depiction of the "mob" and its attitudes closely corresponds to Hegel's. She merely adds, with historical hindsight, its sinister potential for effective organization. In "Antisemitism," the mob had appeared as the denizens of a fairly small, essentially criminal underworld, whose hostility toward respectable society and toward state institutions found an occasional outlet in looting and street violence. Now she extends the category to include the whole host of rogues and adventurers from all of Europe who flocked to the imperialist enterprise, which amounted to a chance for them to indulge in analogous behavior on a vastly enlarged scale. As before, she describes the members of this mob as the "refuse of all classes," "spat out" and rendered "superfluous" by society (pp. 150, 189). More precisely, they are those who had been refused a place among the respectable bourgeoisie on account of bad luck or failure, and who for their own part refused to identify with the hopes of an organized working class (p. 189). She includes among their number such men as Cecil Rhodes and Carl Peters - the leading names, respectively, of English and German expansion in Africa. According to Arendt, this mob writ large was the bourgeoisie's essential partner in the imperialist project, and it did not take long for men like Rhodes and Peters to gain the upper hand. For Arendt that turn of events is hardly fortuitous, but rather confirms her view that the mentalities of the bourgeoisie and mob are essentially continuous: as she sees it, the mob merely dispenses with bourgeois inhibitions and hypocrisy in pursuing essentially similar aims (p. 156).

\section{Racism and Tribal Nationalism}

If the "political emancipation" of the bourgeoisie gave rise to imperialism, that of the mob that followed soon after gave 
rise to something more sinister still: "tribalist" racism as a principle of political organization. In Arendt's account, this form of racism follows antisemitism and imperialism as the third major assault on the body politic. Its hostility to the very idea of the constitutional state is even more fundamental than the other two. While the antisemitic and imperialist politics she has heretofore described seek to commandeer the state for their adherents' immediate aims, the proponents of racism seek to dissolve it altogether, and replace it with an antithetical kind of collectivity. Unlike in the standard contemporary usage of today, Arendt uses the term "racism" exclusively to denote ideologies that demand an explicit, positive identification with one's "race" as the sole basis of political organization. ${ }^{33}$ Her chief examples of such racism are the aspirations of the panGerman and pan-Slavic movements in multi-ethnic Austria and Russia in the decades just before the First World War, and the actual "race society" established in South Africa before then. The essence of racism in this sense is the aspiration to remake all human organization on the basis of putatively "tribal" bonds alone-and thus to destroy the territorial and constitutional constraints that define the modern state.

Unlike racial prejudice, European racism as Arendt defines it appeared fairly recently in modern history. Arendt argues that such racism first emerged as a full-blown worldview only with the imperialist mob's brutal exploitation and massacres of African natives in the late nineteenth century. Its definitive precedent was not any fixed ideas brought over from Europe, but rather the example of the one (formerly) European people whom the later arrivals found already there when they came for South Africa's diamonds and gold: the Boers, the long-isolated descendents of Dutch traders at the Cape. She therefore looks to the Boers' experience as a kind of a "laboratory test" for the potential of this dangerous new ideology (p. 196). As numerous critics have noted, Arendt's portrayal of the Boers and the other Europeans who later joined them in Africa makes for highly uncomfortable reading, for she seems to describe their uncomprehending encounter with the African natives entirely from their own point of view. ${ }^{34}$ "Race,"

33. It is worth recalling that the word "racism" itself had entered English usage only a little more than a decade before Arendt wrote, and its accepted meaning at the time seems to have been largely the same as Arendt's own. See The Oxford English Dictionary, 2nd ed., (1989), s.v.

34. See Kateb, Hannah Arendt: pp. 61-63; compare Benhabib, Reluctant Modernism of Hannah Arendt, pp. 85-86. 
she says, "was the emergency explanation [to account for] human beings whom no European or civilized man could comprehend and whose humanity [sic] so frightened and humiliated the immigrants that they no longer cared to belong to the same human species" (p. 185). According to her, what so "frightened and humiliated" the European arrivals" very "sense of human dignity" was the fact that the natives "treated nature as their undisputed master" and indeed "behaved like a part of nature" themselves, so that they seemed to lack "the specifically human character" that comes with sustaining a "specifically human reality" apart from nature's flux (p. 192). ${ }^{35}$ Arendt's way of putting her point is certainly disconcerting, and is far too clumsily expressed. (Hegel, too, had believed that the tribal peoples of Africa lived in a condition of unmediated dependence on the arbitrary, uncontrollable forces of nature, without any awareness of human freedom or dignity. ${ }^{36}$ But her larger aims must be kept in view. The last thing she would want to do is condone or excuse the murderous treatment of the Africans by the Boers or by the imperialist mob that later aped their brutal example. At the very outset of her chapter on this topic, she says bluntly that the Europeans who adopted the racist "answer" to their affronted "human pride" went on to commit "the most terrible massacres in recent history" (p. 185). ${ }^{37}$ She clearly means to imply that such horrible consequences follow directly from the doctrine of "race" itself, whatever

35. Arendt does not claim that Africa had never known civilizations of its own; indeed, she speculates that the tribes she describes may well have been "the survivors of some unknown disaster which ended a civilization we do not know" (OT, p. 192).

36. More explicitly than Arendt, but in a manner directly continuous with her own account, Hegel had associated the native Africans' immersion in nature with their adherence to animistic beliefs that left no place for individual freedom or responsibility, and a corresponding disregard for the value of human life as such. While he does not suppose, as Arendt does, that the Africans maintained no distinction at all between themselves and the natural world, he does contend that their awareness of this distinction was limited to their illusory belief that they could exert some (arbitrary) control over nature through sorcery. See Hegel, Lectures on the Philosophy of World History: Introduction, trans. H. B. Nisbet (New York: Cambridge, 1975), pp. 177-84, 216.

37. Coming in a book that covers the crimes of Hitler and Stalin, that's quite a claim - though surely a defensible one, given those earlier massacres' untold millions of victims. Arendt follows the claim with more specific indictments of Europeans' crimes in Africa: "the Boers' extermination of the Hottentot tribes, the wild murdering by Carl Peters in German Southeast Africa, the decimation of the peaceful Congo population-from 20 to 40 million reduced to 8 million" (OT, p. 185). 
its initial impetus. Arendt's true purpose in describing the Boers' reaction to the Africans they encountered is in fact not to convey the Boers' own view of the situation as to diagnose the "dangerous perversions of human self-consciousness" to which she says they succumbed as a result (p. 195). Her basic point is that the concept of "human" is inherently universal: to conceive of oneself in a way that would completely deny any commonality with other human beings is possible only through an incoherent distortion of what it is to be a human subject, and likewise a perversion of one's own self-conception as a responsible, purposive agent. The result is "an escape into an irresponsibility where nothing human could any longer exist" (p. 207). As Arendt tells it, the price the Boers paid for repudiating the old Judeo-Christian idea of a universal humanity was the inevitable loss of the very same human capacities that they had first found wanting in the African natives, so that they themselves were soon reduced to the condition of an impotent, lawless "tribe" (p. 194).

Arendt's account of the Boers' rapid degeneration from a civilized people into a "tribe" is intended to demonstrate that any attempt to ground one's human dignity on a contingent trait like ethnic descent or the color of one's skin corrodes the most basic human capacity for responsible, purposive agency. Her underlying thesis is that this basic dimension of human self-consciousness can be sustained only so long as one recognizes that the validity of one's claims upon the world derives from their status as expressions of capacities common to all human beings, not from some such externally determined fact about oneself. That is a deeply Hegelian thesis-perhaps the most profound point of contact with Hegel's thought anywhere in Arendt's work. ${ }^{38}$ While Arendt does not offer much explicit theoretical defense (or even articulation) of such a thesis, her historical narrative follows exactly the argumentative strategy that Hegel himself had employed to that effect. That strategy is to show how a consciousness lacking that awareness of its (universal) humanity inevitably founders on its own incoherencies. Indeed, Arendt's account seems at least loosely patterned on Hegel's own use of this strategy in his famous story of master and slave. For Hegel, the master's vain attempt to assure himself of his own independence from nature, by asserting his absolute superiority over the acquiescent slave, 
inevitably leaves him no less beholden to both external nature and the opacity of his own desires than he was before, and even more so than his slave. ${ }^{39}$ In Arendt's telling, what destroyed the once-civilized Boers' sense of human purpose and responsibility was their very success in lording over the Bantu tribesmen they enslaved as if they were "gods" over them (p. 195). Treating their slaves like no more than expendable "raw materials," and living on them "as one might live on the fruits of wild trees," the Boers quickly lost their forebears' pride in that most basic human accomplishment, the cultivation of the soil (p. 194). They soon chafed against any limitation of law whatsoever, abandoning their homes at the slightest provocation. Arendt particularly stresses the effects of this perversion of human self-consciousness on the Boers' capacity for any lawgoverned political organization even among themselves. Each clan, she says, lived in lawless isolation from all the rest, connected to them by nothing but "tribal" loyalty to their white "race." Having failed to face squarely the "predicament" of the "common sharing of responsibility" implied in the concept of humanity, they proved unable to sustain any true common world of their own. ${ }^{40}$

Arendt takes the Boers' degeneration as a prefigurement of the inevitable consequences of the imperialist mob's more calculated adoption of racist ideology when they arrived to plunder Africa in the late nineteenth century. She also takes it as an object lesson in the inherent tendencies of the "tribal nationalism" of the pan-German and pan-Slavic movements that emerged in the heart of Europe at around the same time. Although Arendt finds all nationalism rather suspect, she still sees a world of difference between the "patriotic" nationalism of a nation-state like France and the entirely "rootless" and avowedly "tribal" kind of the pan-German and pan-Slavic movements, whose adherents she says "had not the slightest idea of patria and patriotism, not the vaguest notion of responsibility for a common, limited community" (p. 232). The former, "patriotic" kind of nationalism is at least in principle compatible with the old

39. See Hegel, Phenomenology of Spirit [1807], trans. A. V. Miller (New York: Oxford, 1977), $\S \S 189-92$.

40. Arendt speaks more explicitly of the "common sharing of responsibility" implied in the idea of humanity, and the attendant "predicament of common responsibility" when faced with human beings radically unlike oneself, when elaborating on this same theme in relation to later forms of "tribal" nationalism back in Europe (OT, p. 236). 
eighteenth-century ideal of a "family of nations" that might peaceably divide the common burden of assuring the human dignity of all. The latter is not: with no political institutions or enduring cultural achievements that they could claim, these movements' leaders instead proclaimed the innate superiority of their German or Slavic "souls"- that is, their inborn, "natural" traits-and were openly hostile to the territorial and legal confines of the constitutional state (pp. 233, 237). Just as she had done in the case of the Boers, Arendt argues that their claim to chosenness amounted to not only a forthright rejection of others' claims to human dignity, but also, in effect, a repudiation of their own.

\section{Statelessness and Human Rights}

According to Arendt, the adherents of "tribal" nationalist movements regard themselves as "stateless," in the sense that they reject the principle of citizenship in a territorially limited, constitutional state (p. 237). The last chapter of "Imperialism" takes up the problem of people who are "stateless" in the more literal sense that no state anywhere recognizes them as its own citizens or nationals. It was only in the decades after the First World War that this status went from being a rare, temporary occurrence to being the permanent condition of hundreds of thousands - and then millions - of people, first in Europe and then around the world. For Arendt, the unique plight of the stateless is that they are invariably "outlaws," regardless of where they go or what they do (p. 295). Because their liberty and even survival depends on the mere indulgence of the police, they may live in constant peril, especially when (like the Jews) they are victims of persecution as well. But that danger of persecution is not Arendt's main concern here. Her concern is rather the inherently debilitating effects of political exclusion on one's potential for human agency, even when one's life or physical well-being are not at risk. In her view, the rights conferred with membership in a formally organized political community are themselves indispensable for living a fully human existence, so much so that to lack them is to be deprived the very basis of human dignity.

Arendt arrives at this conclusion by way of a somewhat confusing polemic against the Enlightenment notion that human 
rights can be conceived as the "natural" endowments of man. What is confusing about this is that it sometimes seems she is arguing against the possibility of universal human rights as such. In fact, the target of her polemic is not the possibility of universal human rights, but simply their supposed status as "natural." The classic formulations of natural rights (by such figures as Locke, Jefferson, and the French Revolution's leaders) refer to rights that human beings are said to possess even in a pre-political state of nature; the free exercise of such rights is supposed to demand nothing but protection from others' trespasses. Arendt argues against this that a human life - if it is to be fully human at all-involves the exercise of capacities that are not even conceivable without membership in some law-governed political community. Such, she contends, is the case of the human capacities for action and for opinion. For a person denied a recognized place in some such community, she says, the former is never "effective," and the latter is never "significant" (p. 296). Even when stateless people are able to move unmolested through their country of sojourn, and can think or say whatever they please, they enjoy no more than "a fool's freedom": their opinions are merely ignored, and their actions inconsequential. Arendt notes that the legal status of people in that situation may actually improve if they resort to crime and get caught: at least then their fate will correspond in some way to their conduct. "For then a criminal offense becomes the best opportunity to regain some kind of human equality, even if it be as a recognized exception to the norm" (p. 286). In all other circumstances, she argues, that fate is wholly out of their hands.

Arendt takes pains to distinguish between the impotence of those excluded from any political community and the more familiar plight of those who suffer oppression or injustice within one. "The calamity of the rightless is not that they are ... not equal before the law, but that no law exists for them; not that they are oppressed but that nobody wants even to oppress them" (pp. 295-96). She grants only one special case in which oppression may involve a similar kind of exclusion: the institution of slavery. What makes slavery comparable to statelessness for her is not the fact of enslavement or exploitation itself (which is simply another form of oppression), but the institutional presumption that such could be some men's "natural" condition. Unlike the victim of oppression, she says, the slave is excluded "even from the possibility of fighting for freedom" ( $p$. 297, emphasis added). She seems to mean by this that the belief 
in the slave's "inborn" servility robs him of any claim on others' solidarity, without which any such fight is doomed in advance. She argues that a stateless refugee adrift in a world carved up into closed nation-states is immobilized in much the same way: like the supposedly "natural" slave, his claims are discounted merely on account of what (or where) he was born.

Arendt concludes from this that a stateless person is "deprived, not of the right to freedom, but the right to action" ( $p$. 296). What he has lost is not an assurance of noninterference in his affairs but the recognition of his agency from others that would be needed for those affairs to make any difference in the world - that is, for his opinions to be "significant" and his actions "consequential." Even without being physically confined or harmed, Arendt suggests, a person denied that recognition is consigned - at least "politically speaking" - to what she calls the condition of "a living corpse." 41 Her reference to a "right" to action in this regard involves a notion of "right" that is rather unusual, at least for the Anglo-American traditions of legal and political thought. It is a "right" in the sense that a criminal has a "right" to get punished for crimes he has committed: in her example of refugee-turned-criminal, it is thus that his status as an "exception to the norm" is finally "recognized." She accordingly says that this "right to action" amounts to "a right ... to live in a framework where one is judged by one's actions and one's opinions" (p. 296). Because the very possibility of specific civil or political rights depend upon the existence of such a framework, she also describes this primary right the stateless have lost as the "the right to have rights."

Once again, Arendt's argument echoes important tenets of Hegel's political thought. For one thing, her curious notion that a criminal's freedom is vindicated through his punishment, so alien to the Anglo-American ear, accords exactly with Hegel's own view of that same matter. ${ }^{42}$ But the consonance between her larger argument and Hegel's runs far deeper than that. The idea that the institutionally mediated recognition of one's agency is an indispensable condition for human freedom and dignity lies at

41. This remark occurs only in Arendt's later German-language version of the text, in the equivalent paragraph to the one in the English-language version containing the statements just quoted. See Arendt, Elemente und Ursprünge totaler Herrschaft (Frankfurt: Deutsche Rechte Europäische Verlagsanstalt, 1955), p. 443, cf. $O T$, p. 296.

42. See $P R \S 100$. 
the very heart of Hegel's political thought. ${ }^{43}$ One could even say that Arendt's entire polemic against "natural" rights amounts to a restatement of his basic contention that not nature but legal and political institutions are what bring human freedom into the world. ${ }^{44}$ For Hegel, full human agency is possible only within a juridical framework that recognizes each person as equal before the law, a framework of formal equality that comes into being historically only with the establishment of the state. Arendt has much the same view:

Equality, in contrast to all that is involved in mere existence, is not given to us, but is the result of human organization insofar as it is guided by the principle of justice. We are not born equal; we become equal as members of a group on the strength of our decision to guarantee ourselves mutually equal rights (p. 301).

We have already seen that Arendt shares with Hegel the belief that human dignity and freedom are incompatible with the kind of unmediated dependence on nature that both thinkers associate with the condition of lawless, "savage" tribes. She now observes that the stateless, too-whatever their personal level of culture-are expelled to a "peculiar state of nature" oddly resembling the one to which such tribes are consigned, merely on account of their lost legal standing. For the stateless, too, live at the mercy of arbitrary forces they can neither control nor comprehend; they, too, are condemned to "live and die without ... having contributed anything to a common world" (p. 300). Just like Hegel, then, Arendt holds that human beings are able to transcend that unfree, "natural" condition only through their recognized place in a political community whose legal institutions embody its members' reciprocal recognition of one another's equal rights. As she now puts it, "Our political life rests on the assumption that we can produce equality through organization, because man can act in and change and build a common world together with his equals and only with his equals" (p. 301).

Unfortunately, much of what Arendt says here about the relationship between the recognition of rights and the exercise of agency is exceedingly cryptic. In particular, her observations on the radical loss of agency suffered by a person denied recogni-

43. See $P R$ §71; Hegel, Philosophy of Mind [1830], trans. William Wallace (New York: Oxford, 1971), §§436-37.

44. See Hegel, Philosophy of Mind, §539; Phenomenology of Spirit, §439. 
tion as a member of a state are not matched by any clear statement of what sort of agency she means to ascribe to a person who enjoys such recognition. At times it seems she means no more than the kind of actions that Hegel, too, had seen were impossible without a framework of law, like owning property and holding a profession. Yet her insistence on distinguishing between the radical plight of those who are entirely excluded from membership in a state, and the more usual one of those who are oppressed or otherwise denied justice within one, suggests that she has something else in mind as well. If the mere fact of membership in a community suffices to bestow "the right to action" even on the oppressed, then that right must involve something other than the reliable enjoyment of full civil rights. The clue to what that might be for her lies in her passing remark that unlike the stateless (or supposedly "natural" slaves), the oppressed at least retain the possibility of fighting for freedoma fight that Arendt says remains "possible under tyranny, and even under the desperate conditions of modern terror" (p. 297). The "right to have rights," then, amounts to the right to claim rights, and if need be to fight for them. Thus she argues not only that a stateless person has been deprived "the legal personality which makes his actions and part of his destiny a consistent whole," as Hegel too might say, but also that such a person has moreover lost "his political status in the struggle of his time" (p. 301). Indeed, Arendt seems to imply that it is precisely through participation in this political struggle that a human being contributes to the making of a "common world" that transcends the futility and dependence of his otherwise "natural" existence. This is certainly very different from Hegel. To be sure, Hegel, too, holds that the mutual recognition upon which the condition of legal right is based arises only out of a history of struggle. But for him that struggle precedes the establishment of the state, and has no place within it. ${ }^{45}$ The citizens of his state need do no more than affirmatively endorse its juridical order as a felicitous fait accompli. For Arendt, by contrast, political recognition entails the chance to take part in what she calls "the daily strife of all citizens," that is, the strife through which further freedoms and justice are won. ${ }^{46}$

The danger that Arendt sees in the unprecedented spread of statelessness throughout the world in her time is not just the im- 
potence and vulnerability of the people condemned to that "peculiar state of nature." She also fears for the effects of their presence on the already-tenuous constitutional institutions of the modern nation-state. As we have seen, the lesson of her earlier excursus on the fate of the Boers had been to show that the concept of humanity is inherently universal: a people cannot coherently refuse to recognize the humanity of others-no matter how foreign those others may seem-without distorting their own self-conception as human agents, and thus subverting their capacity to sustain a "common world" even among themselves. Arendt makes no direct mention of that dark lesson in this later discussion of the crisis of statelessness, but it informs her sense of what is most fundamentally at issue in that crisis. That is the exposure of the deep incoherence that had lurked from the start in the fusion of nation and state (pp. 291-92). Looking back on the interwar years, she sees an immediate manifestation of that incoherence in the general corrosion of the rule of law in countries all over Europe, on account of the arbitrary power exercised by the police over the lives of the swelling numbers of refugees in their custody (pp. 287-89). In Arendt's view, that alone sufficed to undermine the modern nation-state's supposed raison d'être: "Without ... legal equality, which originally was destined to replace the older laws and orders of feudal society, the nation dissolves into an anarchic mass of over- and underprivileged individuals" (p. 290). But Arendt sees a second, perhaps still more destructive manifestation of this incoherence as well. It is that the very fact of consigning the stateless to a "natural" condition prepares the way for a dangerous irruption of "nature" into all political life. "The great danger arising from the existence of people forced to live outside the common world is that they are thrown back, in the midst of civilization, on their natural givenness, on their mere differentiation" (p. 302). The aspect of that "natural givenness" that then takes on political meaning is the one that they share with others-their "national" or ethnic identities. Arendt maintains that the force with which stateless peoples cling to their national identities reflects their perfectly understandable belief that the only reliable protection of rights in a world of nation-states would be to have a nation-state of their own (p. 292). But she fears that such national feeling, based on differentiation by descent rather than loyalty to constitutional institutions, inevitably tends toward "a fierce, violent group consciousness"- that is, toward exactly the kind of atavistic, "tribal" nationalism that we have already seen her portray as a radical 
threat to the very idea of the state. And she also fears that this assertion of irremediable "natural" difference on the part of stateless peoples may provoke a correspondingly tribal recoil on the part of the nation-states confronting them. ${ }^{47}$

Arendt's argument about the hollowness of "natural" human rights leads her to conclude that human rights are meaningful only within the legal framework of an actual political community. And yet that same argument is also meant to show the incoherence, and looming danger, of basing membership in such a community on some more specific "naturally given" quality like national origin. On the one hand, the concept of human rights can be realized only within the confines of a particular state; on the other, the only kind of state that could truly assure such rights would be one that recognizes the universal basis of human dignity. Hegel would have agreed with both of those claims; it was for this very reason that he too had rejected the then-novel notion of national origin as a basis for political allegiance. ${ }^{48}$ But it is only in Arendt's century that the unresolved practical tension between those two claims would emerge as a matter of geopolitical urgency. We can no longer suppose, as someone of Hegel's day still might, that the eventual spread of civilization could suffice to assure human dignity for all. With the system of nation-states already spanning the entire habitable Earth, there is no place left where people denied a place in that system might go to set up political communities of their own. In Arendt's words, "The trouble is that the calamity arose not from any lack of civilization, backwardness, or mere tyranny, but, on the contrary, that it could not be repaired, because there was no longer any 'uncivilized' spot on earth, because whether we like it or not we have really started to live in One World" (p. 297). Moreover, the inability of existing states to assimilate the rising numbers of such people into their communities-even if due to no more than a reasonable concern to set some limits on immigration-undermines

47. See $O T$, pp. 301-302. This passage is very obscure; the comparable passage in Arendt's later German-language version of the text is somewhat clearer. Arendt, Elemente und Ursprünge totaler Herrschaft, pp. 450-51.

48. For Hegel's insistence that the state must recognize its citizens as human beings, not members of any particular ethnic (or religious) group, see $P R \S 209$. For a discussion of Hegel's rejection of nationalism (with textual references), see Terry Pinkard, Hegel's Phenomenology: The Sociality of Reason (New York: Cambridge, 1994), pp. 328, 434n.101. 
their claim to respect for human dignity upon which a truly lawgoverned state must be based. ${ }^{49}$ For Arendt the implication is clear: the assurance of human dignity anywhere now calls for nothing less than deliberate, concerted political action on a global scale, through the establishment of "a new law on Earth" that would guarantee the right of each human being to claim the rights of citizen in some state. ${ }^{50}$

Taking up this theme in The Origins of Totalitarianism's "Concluding Remarks," Arendt says we must wake up to "the bitter realization that nothing has been promised to us"-no "Messianic Age," whether sacred or secular, and no "end of history" either. ${ }^{51}$ (Her reference to the "end of history" is surely an allusion to Alexandre Kojève's famous use of that phrase in his odd declaration that the universal realization of a quasiHegelian state was already well underway.) ${ }^{52}$ And yet even as Arendt denies we stand on the verge of "the end of history," she holds out the hope that we may be in a position to undertake "its first consciously planned beginning" instead. ${ }^{53}$ She argues that this "consciously planned beginning of history" would have to take the form of the founding of "a consciously devised new polity" that would "reintegrate those who in everincreasing numbers are being expelled from humanity and severed from the human condition." 54 What she envisions would not be a single world state, but a framework of law tran-

49. Arendt emphasizes the way in which the influx of stateless refugees during the interwar years in Europe overwhelmed the ability of states like France to maintain any coherent policies on immigration and naturalization, as ordinary aliens discovered they could avoid deportation by claiming the status for themselves $(O T$, p. 286).

50. The phrase "new law on Earth" is used in the Preface to OT's first edition (p. ix); its meaning is clear only in light of the arguments made later on in the book.

51. OT, $1^{\text {st }}$ ed., p. 436. The "Concluding Remarks" appear in the first edition of $O T$ only; this short concluding chapter was dropped in later editions to make room for an additional chapter on totalitarianism. Much, but not all, of the material from the "Concluding Remarks" was shifted to other parts of the text.

52. See Kojève, Introduction, pp. 158-63.

53. $O T, 1^{\text {st }}$ ed., pp. 436.

54. Ibid., $1^{\text {st }}$ ed., p. 439 . While the statement occurs only in the original edition's "Concluding Remarks," Arendt issues a similar demand in the first edition's Preface, which unlike the "Concluding Remarks" was retained in the later editions (OT, p. ix). For broader discussions of Arendt's views on the politics of human rights, see Seyla Benhabib, "Political Geographies in a Global World: Arendtian Reflections" Social Research 69/2 (2002): 539-66; Jeffrey C. Isaac, "A New Guarantee on Earth: Hannah Arendt on Human Dignity and the Politics of Human Rights," American Political Science Review 90/1 (1996). 
scending the sphere of state sovereignty altogether. In practice, her proposal would require no more than for a sufficient number of states to take on a binding legal commitment to extend the status of citizen in one of their communities to any human being denied that status elsewhere. Presumably some international body could determine a fair apportionment of that responsibility in particular cases, much as the pertinent commissions of the United Nations and other multinational bodies do for refugees today. The difference is just that the designated states would have to be legally obligated to extend not just temporary asylum, but full, equal citizenship to the refugees for whom they were made responsible. Yet that difference is great indeed: it would require the participating states to renounce their sovereign privilege to set their own criteria for membership as they see fit. That would mean assuming a burden of common responsibility for humanity that sovereign states have historically been, and continue to be, unwilling to shoulder. In a passage added to the book's revised editions, written with (which omit the first edition's "Concluding Remarks"), Arendt herself voices some doubts over the practical feasibility of founding that kind of global legal order in her time. ${ }^{55}$ But she retracts none of her argument for the imperative urgency of the task.

\section{Epilogue: Totalitarianism}

As noted at the outset of this essay, Arendt had already developed her basic accounts of antisemitism, imperialism and racism-and thus also her views on the fate of the modern state-even before she had arrived at the theory of totalitarianism that she would present in The Origins of Totalitarianism's third and last part. Until she came to write the book's third part, she had regarded Nazism simply as the convergent consummation of those other phenomena. Her new theory of totalitarianism would dramatically depart from that view; rather than proceed as she had intended, by concluding the

55. See $O T$, p. 298. This passage, absent in the first edition, appears for the first time in the German edition of 1955. See Arendt, Elemente und Ursprünge totaler Herrschaft, pp. 450-51. 
book with a single chapter treating Nazism in that light, she instead presents Hitler's regime together with Stalin's as twin instances of a new, wholly unprecedented political evil. ${ }^{56}$ In making that change, Arendt thus adds an entirely new dimension to her picture of the threats to humanity in her time. We have seen that she traces imperialism and racism to the aggressive, self-aggrandizing mentalities that she attributes to the bourgeoisie and mob. By her account, those two groups' alienation from the body politic leads them to the (collective) assertion of their properly private identities, setting them on the precipitous course to an all-consuming rapacity. Arendt's theory of totalitarianism centers on a mentality that is no less alienated from political community, but whose consequent incapacitation is even more profound. She holds that the adherents of the totalitarian "movements" headed by Hitler and Stalin are characterized not by a drive for individual or collective self-assertion, like the bourgeoisie and mob, but instead by a weird disregard for self-interest or even self-preservation. She associates that totalitarian mindset with the group she calls "the masses"-congeries of atomized individuals drawn from any and all social strata, resembling one another in nothing but their political isolation and angry desperation in the face of any adversity. Lacking the basis for a politically productive solidarity, or even mob-style collusion, the mass man's awareness of countless others in similar straits as himself only exacerbates his embittered feelings of his own superfluousness. According to Arendt, what draws such people into totalitarian movements is precisely the fact they find their circumstances unbearably senseless; unlike the racist mob, which seeks an escape from human responsibility, the totalitarian masses seek an escape from human reality as such (pp. 351-52). Arendt argues that totalitarian movements afford just such an escape, first through the "lying world of consistency" conjured up by their leaders' fantastic claims to discern secret, conspiratorial forces lurking behind every event, and then through the organization of the movement itself, which makes those ideological lies the basic facts of their members' daily lives. She further argues that this deep-rooted hostility to "the fortuitousness that pervades reality" is the ultimate reason for the incomparable violence of such a totalitarian movement should it seize political power. The movement's need to sustain the viability of its 
all-encompassing ideological fictions sets it at war with the possibility of human freedom anywhere in the world (p. 458).

Taking Stalin's rule as her primary model, Arendt argues that the first stage of the totalitarian regime's assault on human freedom is the use of arbitrary terror to reduce the entire population under its sway to a condition of impotence much the same as that of the stateless. By meting out "punishments" on the basis of essentially random criteria, without regard for the individual's support or opposition to the regime, such terror severs all connection between the individual's intentions and his fate, and in that way destroys "the juridical person in man" (pp. 433, 447). But whereas statelessness just consigns the individual to practical irrelevance, leaving his private identity intact, Arendt argues that the project of "total domination" sets out to destroy human individuality in its most private manifestations. She contends that the "experiments" in such domination are carried out in the places she deems for this reason "the true central institution" of totalitarian power-the concentration camps (p. 438). She searingly recounts how such camps' macabre routines of torture and deprivation transform the inmates to undifferentiated bodies, little more than interchangeable "bundles of reactions" that predictably cringe in the same way each time (p. 456). Her dark conclusion is that the ultimate aim of totalitarian rule is to yield equivalent results everywhere in its dominion: that is, to reduce every person within its control to no more than a "living corpse"-not just "politically speaking" (as she had qualified the phrase in reference to the stateless) but in every last respect (p. 453).

Arendt's attempt to come to grips with totalitarianism would shift the weight of her fears for her time from the rapacious aggression of imperialism and the "violent group consciousness" of tribalism to this new form of evil, committed by murderers who "are all the more dangerous because they do not care if they themselves are alive or dead, if they ever lived or never were born" (p. 459). And yet none of that changes her sense that all of those evils, totalitarianism included, can be traced to the deep failure of the modern European state to give its people a practical stake in the conduct of public affairs, so that they might actively identify with the state's fundamental mission of upholding human dignity through the universal rule of law. Nor does it alter her conviction that the only response adequate to the crisis of her time is the establishment of a "new law on Earth" on all humanity's behalf, so as to as- 
sure each human being a recognized place in some political community. The only new implication is that the new, law-governed "comity of nations" whose founding she urges would need to face down any regime that through arbitrary terror or concentration camps deprives human beings their basic dignity as purposive agents, without even allowing them to leave. ${ }^{57}$ The horrible novelty of totalitarianism changes only the magnitude, not the meaning, of what Arendt sees as modern humanity's most urgent task. 
Copyright of Review of Politics is the property of University of Notre Dame / Review of Politics and its content may not be copied or emailed to multiple sites or posted to a listserv without the copyright holder's express written permission. However, users may print, download, or email articles for individual use. 
Copyright of Review of Politics is the property of University of Notre Dame / Review of Politics and its content may not be copied or emailed to multiple sites or posted to a listserv without the copyright holder's express written permission. However, users may print, download, or email articles for individual use. 